\title{
PHYSICO-CHEMICAL CHARACTERIZATION OF COCONUT ECOTYPES IN BENIN COASTAL ZONE
}

\author{
Ulysse Ayihaou Daa-Kpode 1,2, Patrice Hodonou Avogbe 3, Gustave Djedatin 4,
} Daniel Datchiglo ${ }^{1}$, Aristide Bakpe ${ }^{1}$, Edmond Sacla Aide ${ }^{5}$, Kolawolé Valère Salako ${ }^{2,5}$, Farid BabaMoussa ${ }^{1}$, Kifouli Adeoti 1,2

${ }^{1}$ Laboratoire de Microbiologie et de Technologie Alimentaire (LAMITA), Faculté des Sciences et Techniques, Université d'Abomey-Calavi, Bénin.

${ }^{2}$ Equipe Biodiversité et Ecologie des Plantes (BDEP), Faculté des Sciences et Techniques, Université

d'Abomey-Calavi, Bénin.

${ }^{3}$ Laboratoire de Biochimie et de Biologie Moléculaire, Faculté des Sciences et Techniques, Université d'Abomey-Calavi, Bénin.

${ }^{4}$ Laboratoire de Biologie moléculaire et de Bioinformatique Appliquée à la génomique; Ecole Nationale Supérieure des Biosciences et Biotechnologies appliquées, Université Nationale des Sciences, Technologies, Ingénieries et Mathématiques (UNSTIM), Bénin.

${ }^{5}$ Laboratoire de Biomathématiques et d'Estimations Forestières (LABEF), Faculté des Sciences Agronomiques, Université d'Abomey-Calavi, Bénin.

Received 31 July 2021

Accepted 14 August2021

Published 31 August 2021

\section{CorrespondingAuthor}

Kifouli Adeoti, zoulade@yahoo.fr

DOI

10.29121/granthaalayah.v9.i8.2021. 4168

Funding: This research received no specific grant from any funding agency in the public, commercial, or not-for-profit sectors.

Copyright: (C) 2021 The Author(s). This is an open access article distributed under the terms of the Creative Commons Attribution License, which permits unrestricted use, distribution, and reproduction in any medium, provided the original author and source are credited.

\section{ABSTRACT}

Coconut water is highly consumed for refreshment due to its nutritional value. However, its nutritional value varies according to the ecotype and stage of maturity of ecotype. In order to identify best ecotypes with high nutritious value, a physico-chemical composition of ten (10) ecotypes was performed at earlier stage of maturity (3 months). The measured parameters were: coconut height, mass of water, total sugar content, soluble sugar content, protein, titratable acidity and $\mathrm{pH}$. The obtained results showed that all parameters vary from one ecotype to another. All coconut ecotypes contain water slightly acid with a $\mathrm{pH}$ value less than 7 . Furthermore, there is no relationship between physical and biochemical parameters. However, within characterized ecotypes, Ecotype_2, appeared to have the best biochemical composition with a significant amount of water. This study provided important informations related to physico-chemical characteristics of coconuts ecotypes found in the coastal zone.

Keywords: Coconut, Water, Physicochemical Characteristics, Benin

\section{INTRODUCTION}

The coconut palm (Cocos Nucifera L.), the only species of the genus Cocos, belongs to the family Arecaceae. It has been described as the most widely cultivated palm in the world Prades (2011). Coconut palm plays an important role in the daily lives of people across tropical area where it is cultivated Chidambaram et al. (2013) . It is a multi-purpose plant with all parts used by humans in food, handicrafts, housing, traditional medicine and many other areas van der Vossen et al. (2007). However, its fruit (coconut) is the most popular. Indeed, the kernel of the fruit has been considered a cash crop for many decades due to its high fat content. Thus, copra (dried kernel) was a processing product, which allowed to obtain coconut oil, an oil rich in lauric acid Prades et al. (2012) 
However, in recent years, the demand for copra has decreased by about $75 \%$ while the demand for fresh or unripe coconut has increased exponentially (300\%) FAO (2009).

Fresh or unripe coconut water is nowadays a common consumer product. It is a sweet, refreshing drink that comes directly from the inner part of the coconut Steiner and Desser (2008) . Thus, there is a growing international demand for coconut water. It is a source of income for thousands of small-scale farmers in Africa and Asia. However, coconut water is not only a refreshing drink. It is also used in traditional medicine Ediriweera (2003) and in microbiology Osazuwa and Ahonkhai (1989). It can also be used to make vinegar Sanchez (1985) and wine Prades et al. (2012). These various uses of coconut water are undoubtedly linked to its biochemical composition. Indeed, several authors Yong et al. (2009), Konan et al. (2016) have shown that the biochemical composition of the water varies according to the variety and the stage of nut's maturity.

In Benin, coconut cultivation is widespread along the coast. Coconuts are consumed fresh in the form of coconut juice, fresh kernel, coconut milk and coconut cream. They are also used in the production of coconut oil Hounhouigan et al. (1998). However, the physical and biochemical characteristics of coconuts from different ecotypes of coconut remain to date undetermined. The present study aimed at characterizing some physical and biochemical parameters of coconut water from unripe nuts of different coconut ecotypes collected in the coastal zone of Benin. This will allow on the one hand to provide indicators that can lead to a better valorization of this product. On the other hand, it will also allow the identification of ecotypes with the best physical and biochemical characteristics that are candidates for coconut improvement program.

\section{MATERIAL AND METHODS}

\subsection{PLANT MATERIAL}

The physical and biochemical parameters were determined on samples from 10 different ecotypes of identified coconut (Table 1). Knowing that these parameters vary according to the age of maturity of the coconut, they are determined for fruits of the same stage of maturity ( 3 months) for all ecotypes. To do this, three (3) trees per ecotype were chosen randomly. On each tree, 3 fruits were randomly selected to form a representative sample from which the different measurements are taken.

\begin{tabular}{|ccc|}
\hline Table $\mathbf{1}$ List of ecotypes characterized & \\
\hline $\mathbf{N}^{\circ}$ & Local or vernacular names & Codification \\
\hline Ecotype_1 & Hibridi_yellow & Var1 \\
\hline Ecotype_2 & Hibridi vôvô & Var2 \\
\hline Ecotype_3 & Hibridi vèvè & Var3 \\
\hline Ecotype_4 & Hibridi Ghanaton & Var4 \\
\hline Ecotype_5 & Sèmè gon & Var5 \\
\hline
\end{tabular}




\begin{tabular}{|ccc}
\hline Ecotype_6 & Agon yovoton & Var6 \\
\hline Ecotype_7 & Agon miton & Var7 \\
\hline Ecotype_8 & Hibridi & Var8 \\
\hline Ecotype_9 & Agon koun & Var9 \\
\hline Ecotype-10 & Agon yovoton_Kpèvi & Var10
\end{tabular}

\subsection{DETERMINATION OF PHYSICAL PARAMETERS}

Several physical parameters were measured on coconuts of different ecotypes. These parameters concerned: height of the fruit, diameter of the fruit, weight of the fruit, weight of dehusked or shelled nut, weight of the fluff, the mass (volume) of water, mass of the almond and the mass of the shell. All measurements were carried on tree samples of each ecotype. The height and diameter of fruit were measured using an electronic caliper, and masses were taken using a precision balance. Specifically, the mass of water was determined according to the method described by Assa et al. (2007).

\subsection{DETERMINATION OF PH AND SOLUBLE SUGAR CONTENT}

The $\mathrm{pH}$ was measured in triplicate using a pH meter (Mettler TOLEDO), and the soluble sugar content by direct measurement always in triplicate using a refractometer according to the AOAC 2000 method.

\subsection{DETERMINATION OF BIOCHEMICAL PARAMETERS}

The protein content was determined by the method described by Zheng et al. (2017). The titratable acidity was determined by the method of (Tyl and Sadler, 2017) and the total sugars content by the colorimetric method reported by Wang et al. (2010) .

\subsection{DATA ANALYSIS}

All analyses and graphics were done in the R 3.5 .1 software environment R Core Team (2018) . Results were analyzed using descriptive statistics, with results expressed as means and standard deviations. Correlations were also performed between parameters and a principal component analysis applied to the correlation matrices generated. The effect of the coconut ecotype on the biochemical and physical parameters was evaluated using linear mixed models in the nlme package Pinheiro et al. (2019). Ecotype was considered as fixed factor while repetition was considered as random factor, and the means were projected in the ggplot2 package Wickham (2009). The relationship between biochemical parameters and physical parameters were assessed using the analysis of common components in the ComDimR package. The relationship between the block (Biochemical and Physical) 
and the variables has been described as well as the relationship within the variables in each block. To achieve this correlation, the fitted means were previously calculated per tree in the emmeans package Russell (2019).

\section{RESULTS AND DISCUSSIONS}

\subsection{VARIATION OF BIOCHEMICAL AND PHYSICAL PARAMETERS ACCORDING TO ECOTYPES}

The biochemical and physical parameters are important criteria of choice for producers and consumers. Analysis of the data shows that the measurements of the biochemical and physical parameters vary significantly from one ecotype to another, except the $\mathrm{pH}$ for which values obtained do not differ significantly. The obtained results were presented on the Table 2 below.

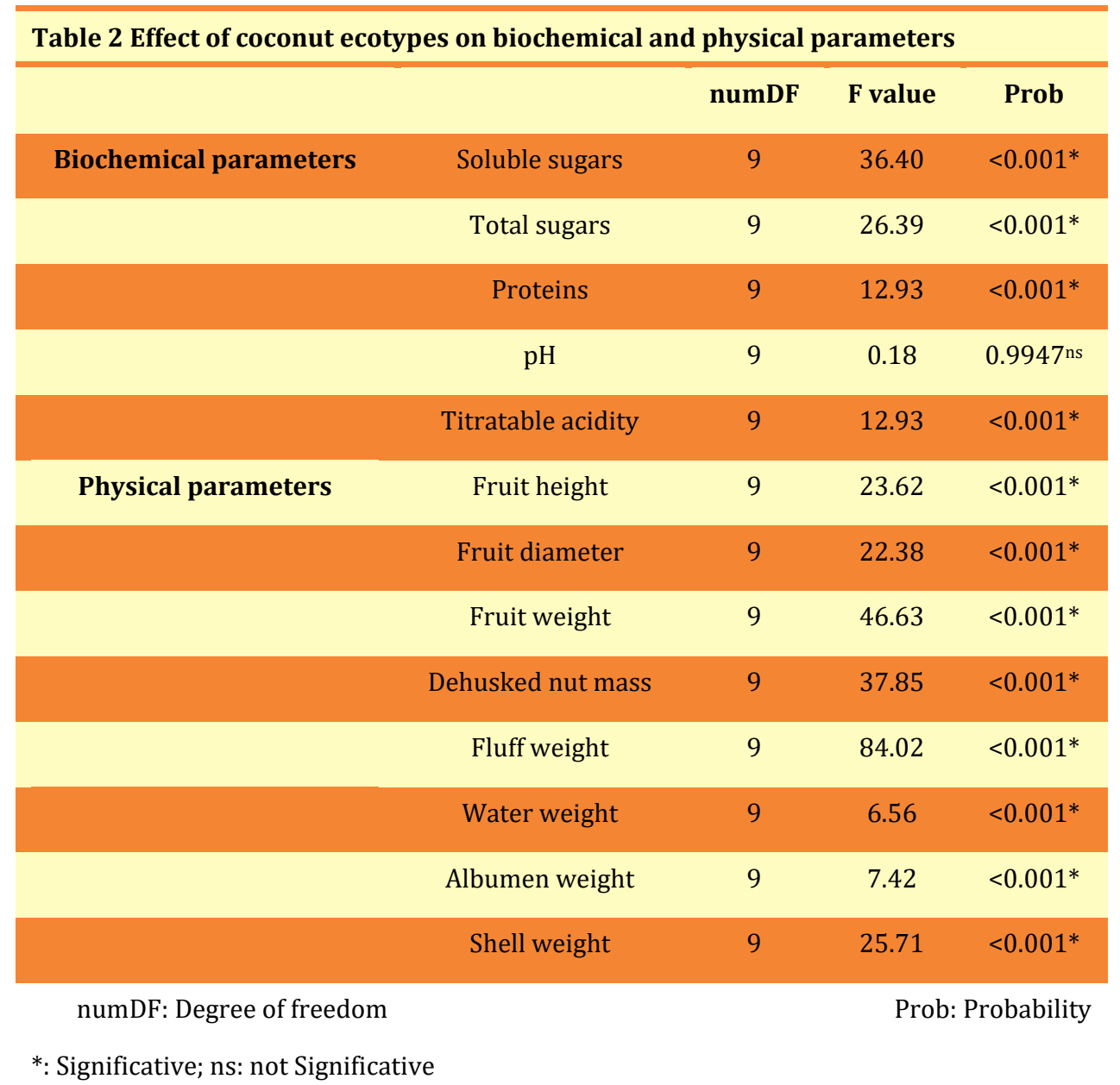

For biochemical parameters (Figure 1a), the highest level of soluble sugars $(5.6 \%)$ is obtained for ecotype_9 while the lowest level $(4.2 \%)$ was measured in ecotype_8. The higest total sugar content (6\%) was observed for ecotype_2 and the lowest level (4.3\%) for ecotype_6. For protein content, the highest value was 
obtained for ecotype_1, and the lowest for ecotype_2. The titratable acidity content varies from 0.35 to 0.62 meq/100gwith the highest value ecotype_ 8 and the lowest for ecotype_2.

Regarding the physical parameters (Figure 1b), statistical analysis revealed that ecotype_10 is the one with the large fruit size (height $=27 \mathrm{~cm}$, diameter $=15.8$ $\mathrm{cm})$. In addition, the fruit of this ecotype also has the highest weight with the greatest mass of fluff.
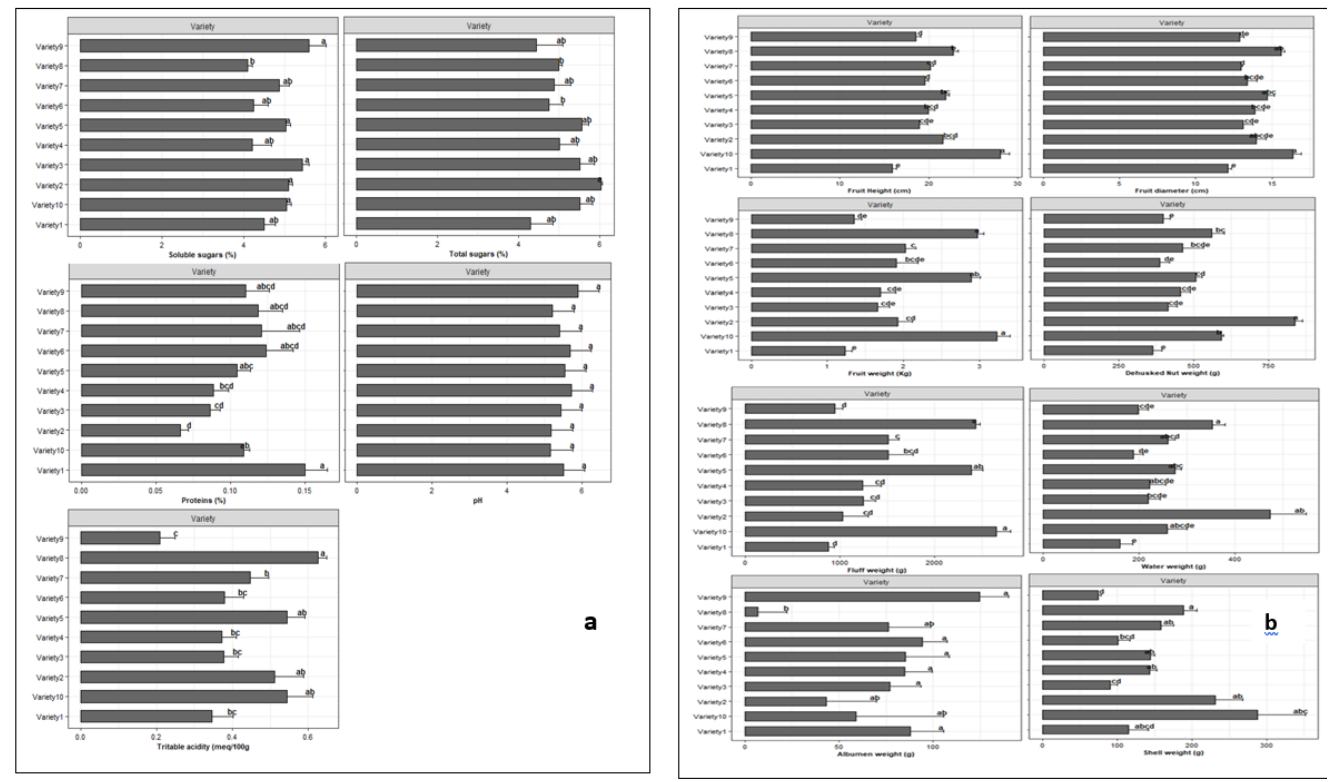

Figure 1 Physico-chemical parameters according coconut variety

\subsection{CORRELATION WITHIN BIOCHEMICAL AND PHYSICAL PARAMETERS}

The obtained results showed that for all samples, biochemical and physical parameters could be considered as two distinct blocks without any relation. No correlation exists both parameters. However, within the biochemical parameters on the one hand and within the physical parameters on the other hand, some correlations were found. A correlation between two variables is found when " $r$ " defined as the correlation coefficient or its absolute value is greater than or equal to 0.5 . Correlation is positive when $0.5<r<1$ and negative when $-1<r<0$.

Figure 2A presented below shows the correlations ( $\mathrm{r}$ ) between the various biochemical parameters studied. It appears clearly that increasing in total sugars content is positively correlated $(\mathrm{r}=0.61)$ with the content of titratable acidity, and negatively correlated with the $\mathrm{pH}(\mathrm{r}=-0.6)$, and proteins content $(\mathrm{r}=-0.80)$. The $\mathrm{pH}$ is also negatively correlated $(\mathrm{r}=-0.61)$ with titratable acidity $(\mathrm{r}=-0.82)$. However, for soluble sugars, no correlation was found between the other parameters. 


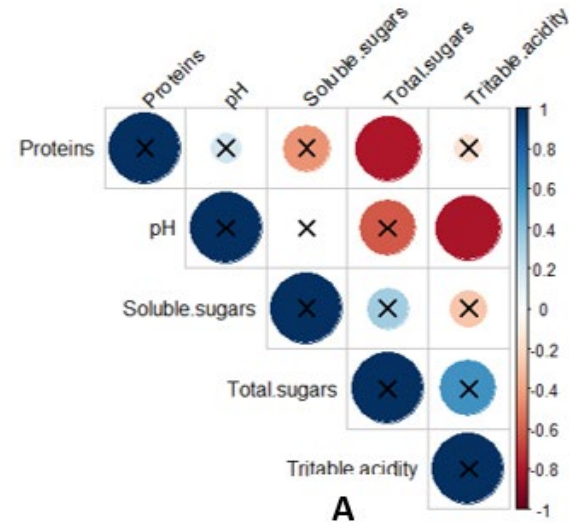

A

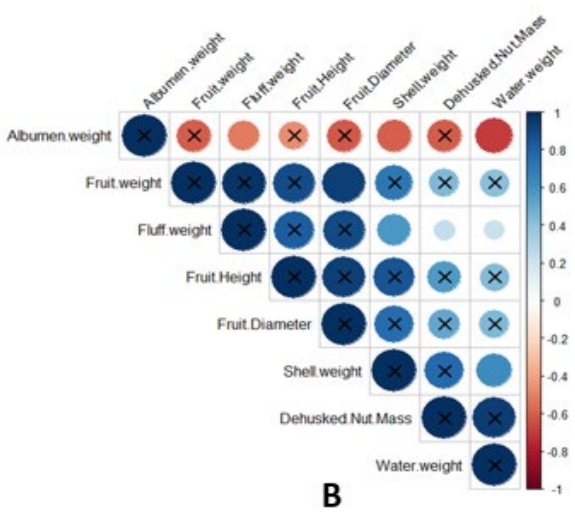

Figure 2 Correlogram between biochemical (A) and physical parameters (B)

When considering physical parameters (Figure 2B), the fruit size is highly positively correlated with the fruit diameter $(\mathrm{r}=0.94)$, the fruit weight $(\mathrm{r}=0.89)$, the fluff weight $(r=0.82)$ and the shell weight $(r=0.85)$. However, the correlation with the dehusked (shelled) nut weight is relatively weak $(r=0.56)$ when compared to the other ones. Indeed, these results show that, the larger the size of the fruit, the greater its weight, diameter, fluff weight, and shell. Moreover, the fruit weight is strongly correlated with the fruit height, the fruit diameter, the fluff weight $(r=0.98)$ and the shell weight $(\mathrm{r}=0.71)$. But it is negatively correlated with albumen weight $(\mathrm{r}=-0.60)$. The shelled nut weight is positively correlated with the fruit height, its diameter, and the shell weight $(r=0.78)$. When the dehusked nut weight increases, the water weight increases $(r=0.95)$ and the albumen weight decreases $(r=-0.60)$. The fluff weight is also positively correlated with the shell weight $(r=0.58)$, and negatively correlated with the albumen weight $(r=-0.57)$. As it is shown on the correlagoram (Figure 2B), an increasing in the water weight, increases the dehusked nut weight and the shell $(\mathrm{r}=0.63)$ while the albumen weight decreases $(\mathrm{r}$ $=-0.69$ ). Shell weight is positively correlated with all other parameters except albumen weight.

\subsection{RELATIONSHIP BETWEEN BIOCHEMICAL PARAMETERS AND ECOTYPES}

In order to establish the different links between the biochemical parameters and the ecotypes, the principal component analysis (PCA) carried out, shows that the first axis (accounting for 55.3\% of total variation out of a sum of $85.5 \%$ for axes 1 and 2) separates ecotypes into two groups according to their biochemical composition (Figure 3). Then, on the one side (right) there is ecotypes with high content of total and soluble sugars, and titratable acidity; and on the other side (left) there is ecotypes with high content of protein. Furthermore, some ecotypes (Var4, Var5 and Var7) were found to have no specific biochemical parameter that made differences with others. 


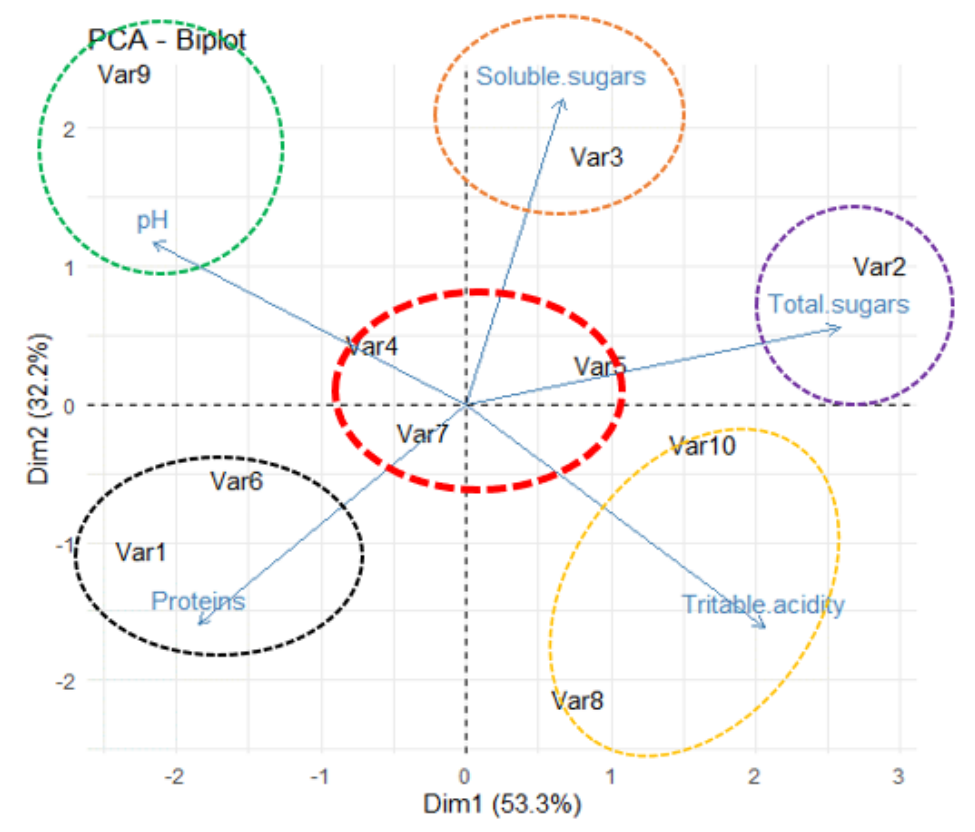

Figure 3 Relationship among biochemical parameters and ecotypes

\subsection{RELATIONSHIP BETWEEN PHYSICAL PARAMETERS AND ECOTYPES}

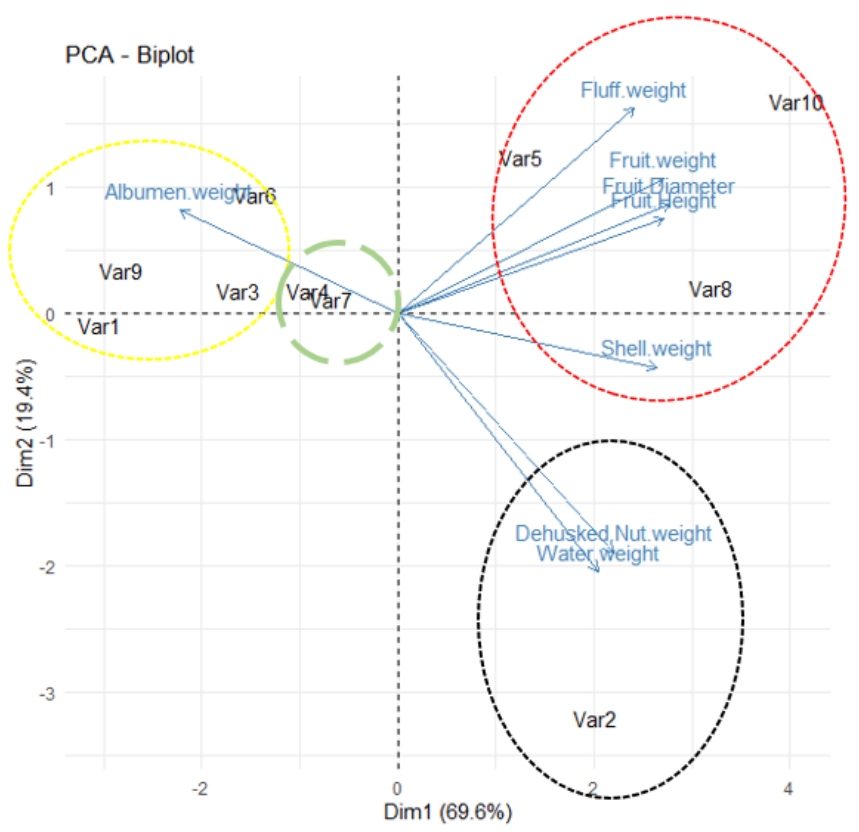

Figure 4 Relationship among physical parameters and ecotypes 
Analogously to the biochemical parameters, a principal component analysis carried out showed that axis 1 separates ecotypes into two categories with a contribute rate of $69.6 \%$ (Figure 4). From the analyses, the ecotypes (Var5, Var8 and Var10) have the best physical parameters, in particular, the fruit height, the fruit diameter, the fruit weight, the fluff weight and the shell weight. The ecotype_2 appears to be which contains a lot of water with a weight of shelled nut. Ecotypes 6 , 9, 3 and 1 are those with a high albumen weight. Furthermore, ecotypes 4 and 7, don't have any specific criteria that could differentiate them from the whole.

\subsection{DISCUSSION}

One of the most common forms of coconut consumption is its water which is preferred at the earlier stage of the nut's maturity. This water is mainly appreciated for its biochemical composition and refreshing effect. Here, our results showed that for same stage of maturity, all biochemical parameters vary from one ecotype to another except the $\mathrm{pH}$. Indeed, all coconut water extracted from ecotypes presented a $\mathrm{pH}$ value less than 7 , which revealed that they are acids. This low acidity presents no risk for consumers. Our results are consistent with those of Benavent and Sanchovzalls, (1992), who reported that the $\mathrm{pH}$ of coconut water is acid. According to Assa et al. (2007), high acidity of coconut water can lead to gastric disorders. Indeed, this variability in the content of biochemical compounds has been also reported in other studies. Indeed, authors underlined that the biochemical composition of coconut water varies according to the stage of maturity, and according to the ecotype Assa et al. (2007), Yong et al. (2009) Kodjo et al. (2015) Konan (2016).

For the physical parameters, the same observation was made. A significant variability of the different data is observed between ecotypes. Our results showed that the larger fruits do not necessarily have the highest water mass. Indeed, there is no correlation between the fruit size, its weight and the mass of water. However, the mass of water depends on the mass of shelled nut. When the mass of shelled nut is high, the mass of the water is also high Prades et al. (2012). Coconuts with a lot of water are not necessarily the ones that are large or fat. As for the ratio, water / albumen, our results showed that ecotypes with a large quantity of water, have less albumen or kernel, which could be explained by the stage of nut's maturity. In fact, at the immature stage, the albumen is still liquid, and a gelatinous layer can be observed in the nut. However, in advanced stage during maturation the albumen is gradually set up and conversely of the water decreases Deffan et al. (2011). Although the physical and biochemical parameters differ from one ecotype to another, there is however, no relation between both parameters. This means that physical parameters do not influence the biochemical composition of the nuts. However, there are links between the biochemical parameters that influence the composition of coconut water. Thus, $\mathrm{pH}$ is closely related to titratable acidity and total sugars. As the $\mathrm{pH}$ increases, the titratable acidity and total sugars decrease. This is perfectly understandable because acidity and $\mathrm{pH}$ are inversely proportional Konan et al. (2016). Indeed, acidity is characterized by the presence of strong and weak acid residues including amino acids, fatty acids and carbon dioxide dissolved in coconut water (Jayalekshmy et al., 1988). These different compounds are produced during metabolic reactions in fruits. Those reactions are often characterized by the oxidation of lipids, proteins and carbohydrates Kodjo et al. (2015). Coconut water from less acidic ecotypes would therefore contain less 
residue. The ecotypes are richer in protein depending on the decrease in total sugars. These results are similar to those obtained by Yong et al. (2009) .

Our results showed that the larger fruits do not necessarily have the highest water mass. Indeed, there is no correlation between the fruit size, its weight and the mass of water. However, the mass of water depends on the mass of shelled nut. When the mass of shelled nut is high, the mass of the water is also high Prades et al. (2012).

\section{CONCLUSION AND RECOMMENDATIONS}

The results obtained during this study allowed us to assess the physicochemical composition of coconut water consumed in the coastal zone of Benin. In view of these results, no correlation exists between biochemical and physical parameters. However, at the earlier stage of nut's maturation, which is the preferred stage of coconut water trade, ecotype_2 appears to be the best for both water's taste and quantity of water. This ecotype could be a good candidate in coconut improvement program.

\section{ACKNOWLEDGEMENTS}

The Authors wish to thank Prof TCHOBO Fidèle and Dr MAZOU Mouaïmine for their support in data acquisition.

\section{REFERENCES}

Assa, R.R., Konan, J.L., Agbo, N., Nemlin, A.P.J. (2007) Caracteristiques physicochimiques de $\mathrm{l}$ ' eau des fruits de quatre cultivars de cocotier ( $\mathrm{C}$ ocos nucifera L .) en Côte d ' Ivoire. Agron Africaine. 19(1):41-51. Retrieved from https://doi.org/10.4314/aga.v19i1.1701

Benavent, V., Sanchovzalls, J. (1992) Analytical validation of coconut water and milk. Alimentaria. 238:59-62.

Chidambaram, S., Singaraja, C., Prasanna, M V., Ganesan, M., Sundararajan, M. (2013) Chemistry of Tender Coconut Water from the Cuddalore Coastal Region in Tamil Nadu, India. Nat Resour Res. 22(2):91-101. Retrieved from https://doi.org/10.1007/s11053-013-9203-y

Deffan, Z.A.B.D., Onan, J..LK.K., Ssa, ARA., Ouame, L.P.K. (2011) Caractérisation Physico-Chimique de l'Amande d'Hybride de Cocotier ( Cocos nucifera L.) PB121 issus de Vitroculture selon les Stades de Maturité et la Durée de Stockage des noix. Sci Nat. 8(1-2):63-72. Retrieved from https://www.ajol.info/index.php/scinat/article/view/92843

Ediriweera, E. (2003) Medicinal uses of coconut (Cocos nucifera L.). Cocoinfo Int.;10:11-21.

FAO. (2009) The state of food and agriculture : Livestock in balance [Internet]. Food and Agriculture Organisation of the United Nations, Rome 2009. 180 p. 
Hounhouigan, J., Rouzière, A., Noël, J.M., Bricas, N., Marouzé, C. (1998) Relance de la production d' huile de coco par la technique de séchage-friture Les techniques. $\quad$ Retrieved from https://agritrop.cirad.fr/390313/1/document_390313.pdf

Kodjo, N.F., Jean-louis, K., Doue, G.G., Didier, S., Yao, M., Allou, K. (2015) Caractérisation physico-chimique des composantes de noix immature et mature de 1 ' hybride de cocotier ( Cocos nucifera L .) Nain Jaune Malaisie x Grand Vanuatu cultivé en Côte d ' Ivoire. J Anim Plant Sci. 27(1) 4193-206. Retrieved from https://www.researchgate.net/profile/YaoSaraka/publication/286448979_Caracterisation_physico-

chimique_des_composantes_de_noix_immature_et_mature_de_l'hybride_de _cocotier_Cocos_nucifera_L_Nain_Jaune_Malaisie_x_Grand_Vanuatu_cultive_ en_Cote_d'Ivoire/links/566d49bd08aea0892c525263/Caracterisationphysico-chimique-des-composantes-de-noix-immature-et-mature-delhybride-de-cocotier-Cocos-nucifera-L-Nain-Jaune-Malaisie-x-GrandVanuatu-cultive-en-Cote-dIvoire.pdf

Konan, B.R., Agnememel, A.B., Akely, P.M.T., Assa, R.R., Konan, K.J.L., Amani, N.G. (2016) Variation des paramètres biochimiques de l'eau de coco (Cocos nucifera L.) issu de la culture in vitro pendant la période de stockage. Int J Biol Chem Sci. 10(3):957. Retrieved from https://doi.org/10.4314/ijbcs.v10i3.4

Osazuwa, O.E., Ahonkhai, I. (1989) Coconut water as growth medium for microorganisms. Niger J Palms Oil Seeds. 10:91-5.

Pinheiro, J., Bates, D., DebRoy, S., Sarkar, D. R Core Team, (2019). nlme: Linear and Nonlinear Mixed Effects Models: R package version 3.1-140. See Retrieved from https//CRAN R-project org/package= nlme.

Prades, A. (2011) Détermination de la qualité de l'eau de coco en fonction du stade de maturation des noix et lors de sa stabilisation par chauffage ohmique et filtration membranaire. Retrieved from https://agritrop.cirad.fr/564179/1/document_564179.pdf

Prades, A., Dornier, M., Diop, N., Pain, J.P. (2012) Coconut water uses, composition and properties: A review. Fruits. 67(2):87-107. Retrieved from https://doi.org/10.1051/fruits/2012002

R Core Team. R (2018) A Language and Environment for Statistical Computing [Internet]. Vienna, Austria; Retrieved from https://www.r-project.org/

Russell L. (2019) emmeans: estimated marginal means, aka least-squares means. R package version 1.4. 2. Retrieved from https://cran.rproject.org/package $=$ emmeans

Sanchez, P.C. (1985) Village-level technology of processing coconut water vinegar. Phil Agr. 68:349-448.

Steiner, I., Desser (2008) A. Coconut water--composition, properties and processing. Ernähr. 32:513-6.

Tyl, C., Sadler, G.D. (2017) pH and Titratable Acidity. In: Nielsen S, editor. Food Analysis. Food Scien. Springer International Publishing 2017. p. 389-406. Retrieved from https://doi.org/10.1007/978-3-319-45776-5_22 
Wang, H., Zhang, Z., Liang, L., Wen, S., Liu, C., Xu, X. (2010) A comparative study of high-performance liquid chromatography and colorimetric method for inulin determination. Eur Food Res Technol. 230(5):701-6. Retrieved from https://doi.org/10.1007/s00217-009-1208-8

Wickham, H. (2009) ggplot2: elegant graphics for data analysis (use R). Springer, New York,. 10:970-8.

Yong, J.W.H., Ge, L., Tan, S.N. (2009) The chemical composition and biological properties of coconut (Cocos Nucifera L.) water. Molecules.;14(12):5144-64. Retrieved from https://doi.org/10.3390/molecules14125144

Zheng, K., Wu, L, He, Z., Yang, B., Yang, Y. (2017) Measurement of the total protein in serum by biuret method with uncertainty evaluation. Measurement.;112:16-21. Retrieved from https://doi.org/10.1016/j.measurement.2017.08.013

van der Vossen, H.A.M., Mashungwa, G.N., Mmolotsi, R.M. Olea europaea L. (2007) Record from Protabase. PROTA (Plant Resour Trop Africa/Ressources végétales l'Afrique Trop Wageningen, Netherlands. 